\title{
Basic Study of a New Soft Resin Applied with Bisfunctional Siloxane Oligomer
}

\author{
Kozo UMEMOTO ${ }^{1}$, Shigeaki KURATA ${ }^{1}$, Kumiko MORISHITA ${ }^{1}$ and Toshio KAWASE ${ }^{2}$ \\ ${ }^{1}$ Department of Biomaterials and Devices, Kanagawa Dental College, 82 Inaoka-cho, Yokosuka, Kanagawa 238, Japan \\ ${ }^{2}$ Department of Dental Bioengineering and Biotechnology, Kanagawa Dental College, 82 Inaoka-cho, Yokosuka, Kanagawa \\ 238, Japan \\ Corresponding author, Shigeaki KURATA; E-mail: kuratas@kdcnet.ac.jp
}

Received March 8, 2007/Accepted April 12, 2007

\begin{abstract}
To make a base polymer of a new soft resin material, a copolymer of 1,3-Bis(methacryloxypropyl)tetramethyl disiloxane (BMPMS) and methyl methacrylate monomer (MMA) was investigated. It was found that the compressive strength, bending strength and bending modulus value of the copolymer decreased with increase in BMPMS concentration. While, transverse deflection increased with increase in BMPMS concentration. As for the $50 \%$ inhibitory concentration value, it was about $0.8 \mathrm{mM}$ for BMPMS.
\end{abstract}

Keywords: Soft resin, Crosslinking agent, Siloxane oligomer

\section{INTRODUCTION}

Silicone-based soft materials are very useful in prosthetic dentistry. However, the bond strength of silicone-based resilient denture liners to denture base resin significantly decreases after thermocycling ${ }^{11}$. This is because bonding is compromised by water invasion, and that PMMA does not have chemical bonding with silicone. To overcome these drawbacks, the authors conceptualized the notion of using a copolymer of silicone material and MMA. This is because MMA has good affinity to PMMA. In particular, 1,3-Bis(methacryloxypropyl)tetramethyl disiloxane (BMPMS) consists of siloxane groups which are sandwiched between two methacryloxy groups $^{2)}$. The methacryloxy groups of BMPMS can thus form chemical bonding with MMA.

The purpose of this study, therefore, was to evaluate the elasticity of a novel copolymer of MMA and BMPMS and the cytotoxicity of BMPMS.

\section{MATERIALS AND METHODS}

\section{Copolymer preparation}

The novel copolymer was prepared using MMA and BMPMS. Chemical formula and molecular weight of BMPMS are listed in Table 1. Experimental concentrations of BMPMS employed for the novel copolymer were 10, 30, 50, and 70 mole\%. Polymerization of the mixed monomers was carried out using the same method described in a previous paper $^{21}$.

\section{Compression and bending tests}

Compressive and bending strengths were measured using a universal testing machine (AGS-500, Shimazu, Co. Ltd., Kyoto, Japan). Crosshead speed of compression test was $2 \mathrm{~mm} / \mathrm{min}$. As for the bending test, crosshead speed was $1 \mathrm{~mm} / \mathrm{min}$ and chart speed was $100 \mathrm{~mm} / \mathrm{min}$. Five compression test pieces with dimensions of $4 \mathrm{~mm}$ diameter $\times 8 \mathrm{~mm}$ length were used, while for the bending test the dimensions used were $4 \mathrm{~mm}$ diameter $\times 25 \mathrm{~mm}$ length. Specimens were stored in $37^{\circ} \mathrm{C}$ water for 50 \pm 2 hours prior to the tests. To determine the bending strength, specimen was placed in a threepoint bending fixture with a span of $20 \mathrm{~mm}$. Bending modulus was calculated from the linear portion of the load-time curve up to the proportional limit. Applied load for transverse deflection was 1.5$5.0 \mathrm{kgf}$.

\section{Cytotoxicity test}

Handling and culture of the tooth pulp was carried out according to the method of Kawase et al.3. Tooth pulp was taken out from human extracted tooth with informed consent. Following random cell migration in human pulp tissue specimen, human pulp cells were subcultured at $37^{\circ} \mathrm{C}, 5 \% \mathrm{CO}_{2}-95 \%$ air, and $95 \%$ humidity. The liquid medium of cell suspension culture at $3 \times 10^{4}$ cells $/ \mathrm{ml}$ density was dispensed into $200-\mu \mathrm{l}$ wells of a 96 -well culture plate. The cells were cultivated for two days. After which, the culture solution was replaced with $200-\mu$ l culture solutions containing varying concentrations of BMPMS, from 0.1 to $5 \mathrm{mM}$.

BMPMS-containing solutions were inoculated for two days and the cells were cultivated for six days. On every inoculation day, one culture plate was collected to determine the DNA content of cells. Each plate was then washed two times with physiological saline and stored in the freezing chamber until analysis. Time-dependent cell proliferation was measured by DNA quantitative analysis ${ }^{4}$. 
Table 1 Chemical formula, molecular weight, and code of siloxane oligomer

\begin{tabular}{|c|c|c|c|c|}
\hline Chemical formula & \multicolumn{2}{|c|}{ Structural formula } & $\mathrm{Mw}$ & Code \\
\hline & $\mathrm{CH}_{2} \mathrm{CH}_{2}$ & $\mathrm{CH}_{3}$ & & \\
\hline $\begin{array}{l}\text { 1,3-Bis(3-methacryloxypropyl)- } \\
\text { 1,1,3,3-tetramethyl disiloxane }\end{array}$ & $\mathrm{CH}_{2}=\mathrm{CCO}_{2}\left(\mathrm{CH}_{2}\right) \operatorname{SiOSi}(\mathrm{C}$ & $\mathrm{C}=\mathrm{CH}_{2}$ & 386.7 & BMPMS \\
\hline
\end{tabular}

Table 2 Effect of BMPMS addition on the mechanical properties of PMMA

\begin{tabular}{ccccc}
\hline $\begin{array}{c}\text { Specimen (mol\% of } \\
\text { BMPMS in PMMA) }\end{array}$ & $\begin{array}{c}\text { Compressive } \\
\text { strength }(\mathrm{MPa})\end{array}$ & $\begin{array}{c}\text { Bending strength } \\
(\mathrm{MPa})\end{array}$ & $\begin{array}{c}\text { Bending modulus } \\
(\mathrm{GPa})\end{array}$ & $\begin{array}{c}\text { Transverse deflection } \\
\text { value } \\
(\mathrm{mm})^{*}\end{array}$ \\
\hline PMMA & $113 \pm 3^{\mathrm{a}}$ & $124 \pm 2^{\mathrm{a}}$ & $2.93 \pm 0.10^{\mathrm{a}}$ & $0.15 \pm 0.00^{\mathrm{a}}$ \\
$10 \%$ BMPMS & $71 \pm 3^{\mathrm{b}}$ & $95 \pm 5^{\mathrm{b}}$ & $1.98 \pm 0.26^{\mathrm{b}}$ & $0.29 \pm 0.03^{\mathrm{b}}$ \\
$30 \%$ BMPMS & $52 \pm 3^{\mathrm{c}}$ & $70 \pm 8^{\mathrm{c}}$ & $1.39 \pm 0.10^{\mathrm{c}}$ & $0.40 \pm 0.02^{\mathrm{c}}$ \\
$50 \%$ BMPMS & $43 \pm 1^{\mathrm{d}}$ & $55 \pm 2^{\mathrm{d}}$ & $1.18 \pm 0.02^{\mathrm{d}}$ & $0.46 \pm 0.01^{\mathrm{d}}$ \\
$70 \%$ BMPMS & $37 \pm 3^{\mathrm{e}}$ & $48 \pm 1^{\mathrm{e}}$ & $1.08 \pm 0.04^{\mathrm{e}}$ & $0.48 \pm 0.01^{\mathrm{e}}$ \\
\hline
\end{tabular}

Same superscript letter indicates no significant differences in each test group $(P>0.05)$.

* Load of transverse deflaction was 1.5-5.0 kgf and distance of support span was $20 \mathrm{~mm}$.

\section{Statistical analysis}

All data collected in this study were analyzed statistically using Student's t-test.

\section{RESULTS}

Table 2 shows the compressive strength, bending strength, bending modulus, and transverse deflection value. Compressive strength of PMMA was $118 \pm 3$ $\mathrm{MPa}$. As for the copolymers containing 10, 30, 50, and $70 \mathrm{~mol} \%$ BMPMS, their compressive strengths were $71 \pm 3,52 \pm 3,43 \pm 1$, and $37 \pm 3 \mathrm{MPa}$ respectively. Therefore, there were apparent significant differences between the PMMA value and those of the copolymers $(\mathrm{P}<0.05)$.

The bending strength and bending modulus of PMMA were $124 \pm 2 \mathrm{MPa}$ and $2.93 \pm 0.10 \mathrm{GPa}$ respectively. As for the bending strength and bending modulus of the copolymers, they decreased with increase in BMPMS concentration. Similarly, there were significant differences between the PMMA value and those of the copolymers in both properties $(\mathrm{P}<0.05)$. In particular, the bending strength and bending modulus of 70 mol\% BMPMS were $48 \pm 1$ $\mathrm{MPa}$ and $1.08 \pm 0.04 \mathrm{GPa}$ respectively.

In terms of transverse deflection, the value of PMMA was $0.15 \pm 0.00 \mathrm{~mm}$. Those of copolymers containing 10, 30, 50, and $70 \mathrm{~mol} \%$ BMPMS were $0.29 \pm 0.03,0.40 \pm 0.02,0.46 \pm 0.01$, and $0.48 \pm 0.01 \mathrm{~mm}$ respectively. It could be seen that the transverse deflection value of the copolymers increased with increase in BMPMS concentration. There were also significant differences between the PMMA value and those of the copolymers $(\mathrm{P}<0.05)$.

As for the $50 \%$ inhibitory concentration $\left(\mathrm{IC}_{50}\right)^{5)}$ of

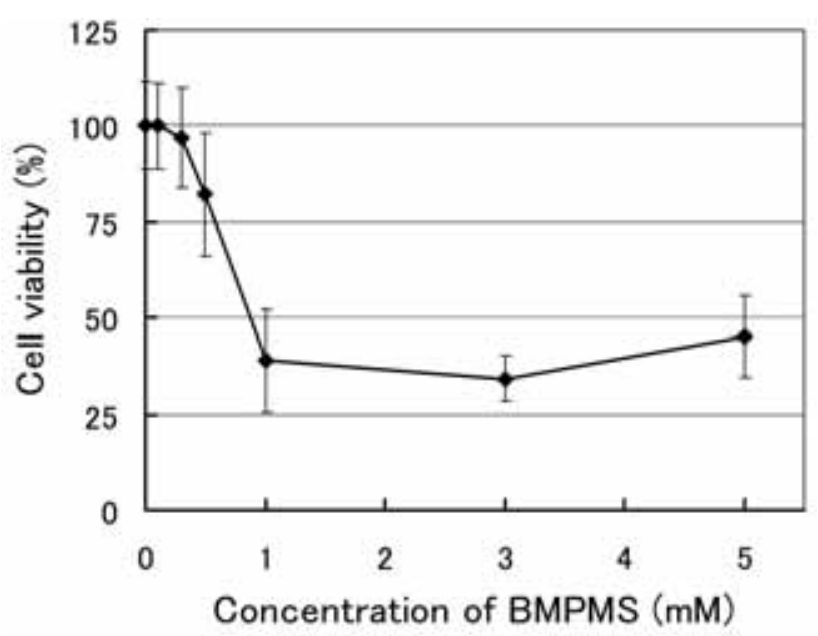

Fig. 1 Biological evaluation of BMPMS using cell culture test.

BMPMS, it was shown in Fig. 1 to be about $0.8 \mathrm{mM}$.

\section{DISCUSSION}

In siloxane oligomers, rotation about the silicone-tooxygen bond is almost zero, since the rotation being virtually free ${ }^{6,7}$. When this property is coupled with the crosslinking of polydimethylsiloxanes, rubber products with good elastic properties can be yielded ${ }^{8}$. BMPMS, which has dimethylsiloxane chain, can thus be crosslinked too. As a result, the copolymer of BMPMS and MMA showed high elasticity.

It was reported that the bond strength of silicone-based soft lining materials to acrylic resin decreased after storage in distilled water ${ }^{9}$. Silicone materials have no effect on bonding to PMMA. 
Thus, the copolymer of BMPMS and MMA was expected to show better affinity to PMMA than silicone materials. BMPMS is an oily compound with a molecular weight of 386.7. The addition of BMPMS to MMA was found to decrease the water sorption of the resin significantly when compared with that of $\mathrm{PMMA}^{2}$. In the same vein, Miyasaka et al. reported that silyl-dimethacrylates were likewise effective as additional monomers in dental composites to improve water repellency ${ }^{10}$. This was because the hydrophobic property prevented water invasion, and thus ensured the good affinity between the copolymer and PMMA. However, silicone-based materials have several disadvantages. For example, autopolymerizing silicone materials exhibited severe, and surface roughness changes caused by denture cleansers ${ }^{11)}$. It should be cautioned that daily cleansing of soft lining materials with mismatched denture cleansers could promote subsequent biofilm formation of fungi on the materials ${ }^{12)}$. Clinically, colonization by Candida albicans on denture soft lining materials is recognized as a dental problem ${ }^{13}$. Thus, to avoid the formation of Candida albicans biofilms, silicone materials must have a potent antimicrobial property and high solvent resistance.

In the biological evaluation of BMPMS using cell culture test, $\mathrm{IC}_{50}$ of BMPMS was about $309 \mu \mathrm{g} / \mathrm{ml}$. Therefore, the cytotoxicity of BMPMS was higher than that of $\mathrm{MMA}^{14,15)}$, but lower than that of BisGMA $^{16)}$.

\section{REFERENCES}

1) Kulak - Ozkan Y, Sertgoz A, Gedik H. Effect of thermocycling on tensile bond strength of six siliconebased, resilient denture liners. J Prosthet Dent 2003; 89: 303-310.

2) Umemoto K, Kurata S. Study on a new cross-linking agent with low water sorption for poly(methyl methacrylate). Bull Kanagawa Dent Col 1993; 21: 1115.

3) Kawase T, Sato S, Yamada M, Hirayama A, Miake $\mathrm{K}$, Saito S. Human periodontal ligament cells in vitro: Characterization of alkaline phosphatase. J
Bone Mineral Res 1986; 1(Suppl 1, Abstr): 63.

4) Puzas JE, Goodman DBP. A rapid assay for cellular deoxyribonucleic acid. Anal Biochem 1977; 86: 50-55.

5) Takeda S, Hashimoto Y, Miura Y, Kimura Y, Nakamura M. Cytotoxicity test of dental monomers using serum-free cell culture (in vitro). $J \mathrm{~J}$ Dent Mater 1993; 12: 613-619.

6) Tobolsky AV. Properties and structure of polymers, 2nd ed, John Wiley \& Sons Inc., New York, 1962, p.67.

7) Owen MJ. Why silicones behave funny. Chemtech 1981; May: 288-292.

8) McCabe JF. Soft lining materials: composition and structure. J Oral Rehabil 1976; 3: 273-278.

9) Yanıkoglu N, Denizoglu S. The effect of different solutions on the bonding strength of soft lining materials to acrylic resin. Dent Mater J 2006; 25: 3944.

10) Miyasaka T, Yoshida T, Ohtake Y. Application of silyl-dimethacrylate to dental composite resin. J J Dent Mater 2006; 25: 267-274.

11) Jin C, Nikawa H, Makihira S, Hamada T, Furukawa $\mathrm{M}$, Murata $\mathrm{H}$. Changes in surface roughness and color stability of soft denture lining materials caused by denture cleansers. J Oral Rehabil 2003; 30: 125130.

12) Nikawa H, Jin C, Makihira S, Egusa H, Hamada T, Kumagai H. Biofilm formation of Candida albicans on the surfaces of deteriorated soft denture lining materials caused by denture cleansers in vitro. J Oral Rehabil 2003; 30: 243-250.

13) Price C, Waters MGJ, Williams DW, Lewis MAO, Stickler D. Surface modification of an experimental silicone rubber aimed at reducing initial candidal adhesion. J Biomed Mater Res 2002; 63: 122-128.

14) Shimoyama K, Kurata S, Morishita K. Mechanical properties of resin material using various hydrophobic methacrylate monomers and cytotoxicity of hydrophobic methacrylate monomers on human pulp fibroblasts. Kanagawa Shigaku 2003; 38: 1-9.

15) Jinno S, Kawai T, Ishikawa A, Suzuki T, Hattori N, Okeya H, Hayashi T, Maeda H, Ohno Y, Ito M, Noguchi T. Influence of novel resin monomer on viability of L-929 mouse fibroblasts in vitro. Dent Mater J 2006; 25: 693-699.

16) Hikage S, Sakaguchi K. Cytotoxicity of a metal primer for precious alloys. J J Dent Mater 1992; 11: $57-64$ 